\title{
ASEAN-CHINA FTA AND THE IMPACT ON INDONESIAN MANUFACTURING INDUSTRY
}

\author{
Mohamed Aslam \\ Faculty of Economics and Administration \\ University of Malaya \\ (maslam@um.edu.my) \\ DOI: https://doi.org/10.22452/jati.vol23no1.2
}

\begin{abstract}
In November 2002, ASEAN and China signed a Free Trade Area (FTA) agreement. Before 2002, there was an estimation that both regions would gain from FTA deals. However, the rapid growth of China since the early 1990s had caused trade and investment diversions to ASEAN. The strong competition between the regions in the international commodity market and productive foreign capital has produced a great deal of stress within ASEAN economies. The economic stress is largely attributed to the structure and similarity of production and exports of ASEAN and China. Theoretically only countries that have the lowest cost of production will gain in trading. Today, nearly 14 years after the agreement was signed, the picture of competitiveness in the commodity market should show a new trend of competitiveness. With respect to Indonesia, the Business Chamber of Commerce Indonesia (KADIN) and industrialists, had complained that the ACFTA actually caused losses to local manufacturers and businesses, in particular consumer goods products such as textile and clothing, and electrical and electronics sectors. This paper investigates the impacts of the ACFTA on the Indonesian manufacturing sector. For the investigation this paper employs various trade performances indices such as revealed comparative advantage, intra-industry trade, and the Hillman index.
\end{abstract}

Keywords: ASEAN, China, Indonesia, FTA, RCA, Hillman index, intra-industry trade

\section{ASEAN-CHINA FTA: A Brief Review}

The idea to establish a free trade area between ASEAN and China was mooted by Zho Rongji, the former Prime Minister of the People's Republic of China 
(hereafter China), during the ASEAN +3 meeting in Manila, Philippines in 1998. Then in November 2000 China raised the idea of an ASEAN-China Free Trade Area (ACFTA) during the ASEAN +3 meeting in Singapore, and at the ASEAN-China Economic Cooperation Meeting in August 2001 (Buszynski, 2001). On 4 November 2002, in Phnom Penh, Cambodia 10 members of ASEAN and China reached an agreement to build an ACFTA. Both regions signed the Framework Agreement on Comprehensive Economic Co-operation (CEC). The agreement set the elements and basis for negotiations toward the realisation of an ASEAN-China Free Trade Area by 2010 for the six main ASEAN members (Indonesia, Malaysia, Thailand, Singapore, the Philippines, and Brunei) (ASEAN6) and by 2015 for the four new ASEAN members (Cambodia, Laos, Myanmar, and Vietnam) (CLMV). The ACFTA was implemented on 1 January 2010. Between 2002 and 2014, over 10 key economic agreements and protocols were concluded such as the Framework Agreement that includes provisions such as to establish ACFTA within 10 years, Trade in Goods, Early Harvest Programme, Trade in Services, Trade in Investment, Dispute Settlement Mechanism, and Economic Co-operation.

For the first phase of the ACFTA, members have implemented the Early Harvest Programme (EHP). This EHP is an integral part of the ASEANChina FTA Comprehensive Economic Cooperation (CEC) framework. Under the EHP, tariff reductions or elimination, or liberalising trade in goods falls, the reduction or elimination of tariffs on listed products was to be gradually implemented. Tariff reductions under the FTA agreement were based on applied MFN rates as of 1 July 2003 (Mohamed Aslam, 2004). In the case of ASEAN members that were not members of WTO, tariff reductions were based on MFN rates applied by China. Additionally, the Agreement categorised products for tariff reduction into two tracks, namely, normal and sensitive. Products listed in the normal track by a member of ACFTA had to reduce or eliminate tariff rates gradually from 1 January 2005 to 2010 and applies to ASEAN-6 and China. In the case of the newer ASEAN member states, (CLMV), the period of tariff liberalisation was from 1 January 2005 to 2015. For these countries, the starting tariff rates are higher with a different period for tariff liberalisation. ASEAN and China had to implement tariff reductions or elimination no later than 1 January 2004 between 0 to 10 percent. By 1 January 2006, trade between ASEAN and China should have been operating under zero tariffs so that by 2006 goods traded between the regions would move across borders freely. Nearly $95 \%$ of the products on both sides have realized zero tariffs. Both sides had reduced tariff rates, but before the 
ACFTA was upgraded in 2015, the tariff rates in China were still quite high compared to members of ASEAN, except for Thailand and Vietnam (Table 1).

Table 1: Selected East and Southeast Asia Countries: Tariff Rates (Percentages)

\begin{tabular}{|c|c|c|c|c|c|c|c|}
\hline \multirow[t]{2}{*}{ Country } & \multirow{2}{*}{$\begin{array}{c}\text { Recent } \\
\text { Year }\end{array}$} & \multicolumn{4}{|c|}{ All products } & \multirow{2}{*}{$\begin{array}{c}\begin{array}{c}\text { Primary } \\
\text { Products }\end{array} \\
\text { Simple } \\
\text { Mean } \\
\text { tariff }\end{array}$} & \multirow{2}{*}{$\begin{array}{c}\begin{array}{c}\text { Manufactured } \\
\text { products }\end{array} \\
\text { Simple } \\
\text { Mean } \\
\text { tariff }\end{array}$} \\
\hline & & $\begin{array}{c}\text { Binding } \\
\text { Coverage }\end{array}$ & $\begin{array}{c}\text { Simple } \\
\text { Mean } \\
\text { tariff }\end{array}$ & $\begin{array}{c}\% \text { of tariff } \\
\text { Lines with } \\
\text { International } \\
\text { peaks }\end{array}$ & $\begin{array}{c}\% \text { of } \\
\text { Tariff } \\
\text { With } \\
\text { Specific } \\
\text { rates }\end{array}$ & & \\
\hline China & 2014 & 100 & 7.6 & 16.18 & 0.1 & 7.6 & 7.6 \\
\hline Japan & 2014 & 99.6 & 2.4 & 7.78 & 4.9 & 4.8 & 2 \\
\hline Korea & 2014 & 94.1 & 5.2 & 4.36 & 0.4 & 16.8 & 3 \\
\hline Indonesia & 2013 & 96.6 & 5 & 7.65 & 0.5 & 3.4 & 5.2 \\
\hline Malaysia & 2009 & 84 & 5.3 & 15.93 & 0.7 & 2.4 & 5.8 \\
\hline Philippines & 2010 & 66.9 & 4.8 & 4.89 & 0 & 6.3 & 4.6 \\
\hline Singapore & 2014 & 70.8 & 0 & 0 & 0.1 & 0 & 0 \\
\hline Thailand & 2014 & 76.5 & 8.2 & 16.94 & 3.7 & 11.1 & 7.7 \\
\hline Viet Nam & 2014 & 100 & 6.6 & 20.88 & 0.5 & 8 & 6.4 \\
\hline
\end{tabular}

Notes:

1. Binding coverage is the percentage of product lines with an agreed bound rate. Bound rates result from trade negotiations incorporated into a country's schedule of concessions and are thus enforceable.

2. All products. Simple mean applied tariff is the unweighted average of effectively applied rates for all products subject to tariffs calculated for all traded goods. Data are classified using the Harmonized System of trade at the six- or eight-digit level. Tariff line data were matched to Standard International Trade Classification (SITC) revision 3 codes to define commodity groups. Effectively applied tariff rates at the six- and eight-digit product level are averaged for products in each commodity group. When the effectively applied rate is unavailable, the most favored nation rate is used instead. To the extent possible, specific rates have been converted to their ad valorem equivalent rates and have been included in the calculation of simple mean tariffs.

3. Column 5. Share of tariff lines with international peaks is the share of lines in the tariff schedule with tariff rates that exceed 15 percent. It provides an indication of how selectively tariffs are applied.

4. Column 6. Share of tariff lines with specific rates is the share of lines in the tariff schedule that are set on a per unit basis or that combine ad valorem and per unit rates. It shows the extent to which countries use tariffs based on physical quantities or other, non-ad valorem measures. 
5. Primary Products. Simple mean applied tariff is the unweighted average of effectively applied rates for all products subject to tariffs calculated for all traded goods. Data are classified using the Harmonized System of trade at the six- or eight-digit level. Tariff line data were matched to Standard International Trade Classification (SITC) revision 3 codes to define commodity groups. Effectively applied tariff rates at the six- and eight-digit product level are averaged for products in each commodity group. When the effectively applied rate is unavailable, the most favored nation rate is used instead. To the extent possible, specific rates have been converted to their ad valorem equivalent rates and have been included in the calculation of simple mean tariffs. Primary products are commodities classified in SITC revision 3 sections 0-4 plus division 68 (nonferrous metals).

6. Manufactured products. Simple mean applied tariff is the unweighted average of effectively applied rates for all products subject to tariffs calculated for all traded goods. Data are classified using the Harmonized System of trade at the sixor eight-digit level. Tariff line data were matched to Standard International Trade Classification (SITC) revision 3 codes to define commodity groups. Effectively applied tariff rates at the six- and eight-digit product level are averaged for products in each commodity group. When the effectively applied rate is unavailable, the most favored nation rate is used instead. To the extent possible, specific rates have been converted to their ad valorem equivalent rates and have been included in the calculation of simple mean tariffs. Manufactured products are commodities classified in SITC revision 3 sections 5-8 excluding division 68.

Source: World Bank Development Indicator, http://wdi.worldbank.org.

Economic relations between ASEAN and China became more intense after the signing of the Framework Agreement on CEC. Subsequently, the ASEANChina Free Trade Agreement had increased trade and investments flows between ASEAN and China. In August 2014, China and ASEAN negotiated to upgrade the level of ACFTA after four rounds of negotiations. The upgraded agreement was signed in Kuala Lumpur on 22 November 2015. The upgraded Free Trade Area agreement was designed to enhance and drive fresh regional cooperation between the two parties. Both sides agreed to deepen and expand cooperation in trade and economic sectors covering a wide range of areas including goods, services, investment, economic and technological cooperation. In the upgrading negotiations, both sides emphasized strengthening the facilitation of trade in goods and investments to further open the service market and improve the level of economic and technical cooperation. China and ASEAN plans to expand two-way trade to USD\$1 trillion by 2020 . 
Although trade between ASEAN and China had increased substantially as stated above, this paper asserts that there would be stiff competition between ASEAN and China. The competition will occur in two aspects: (1) international market penetration, and (2) competition in terms of products (Mohamed Aslam, 2004). As the data shows, whatever product is produced and exported by ASEAN is also produced and exported by China. Since there are similarities between China's and ASEAN's production in the manufacturing sector and exports and given that the impressive expansion of China's manufacturing sector since the early 1990s, it is believed that the ACFTA will adversely affect industries in ASEAN and that trade growth of ASEAN members will eventually slow down (Lardy, 2002). Plans for tariff liberalisation and NTB tariffication under the ACFTA Framework will definitely result in significant harm to domestic-oriented and export-oriented industries in ASEAN countries (Mohamed Aslam, 2004).

If there is a possibility of intense competition from China under the ACFTA, how will members of ASEAN ensure that their industries remain competitive? Using a case study, this paper investigates the impact of ACFTA on Indonesian manufacturing industries (producers and or exporters) with the question of: Is it true that the ACFTA has caused losses to the Indonesian manufactures? To examine the issue this paper employs a simple method to investigate the impacts utilising various trade performances indices such as revealed comparative advantage, intra-industry trade and the Hillman index. To a certain extent these indices are able to show the impact of ACFTA on Indonesia's manufacturing sector.

\section{ASEAN-China Trade}

China's economy has grown rapidly since the 1990s. The country's real GDP growth during the last decade has averaged about $10 \%$, and is the fastest rate of real GDP growth in the world. The total trade of China in the world economy has increased from 1\% in 1980 to $1.70 \%$ in 1990, and in 2015 the ratio had been recorded at 4.5\%. From 1991 to 2015, China's foreign trade grew at an average annual rate of $18 \%$. China's exports have grown over $3000 \%$ from $\$ 62.1$ billion in 1990 to $\$ 2,282$ billion in 2015, making China the third largest exporter in the world. Comparatively, foreign trade in ASEAN grew at an average annual rate of $10.1 \%$ from 1991 to 2015 . Foreign trade is an important driving force for the economic development of China and ASEAN. ASEAN countries rely more on the exports sector for economic growth as compared to China. But China seems to have a greater advantage in trading with ASEAN. 
The former Prime Minister of Singapore and mentored by the late Mr. Lee Kuan Yew issued a statement that the overwhelming economic growth of China would somehow determine the future economic growth of ASEAN. The former Prime Minister of Singapore, Mr. Goh Chok Tong, stated that, "Our biggest challenge is... to secure a niche for ourselves as China swamps the world with her high-quality but cheaper products" (Panitchpakdi \& Clifford, 2002, p. 103). He also warned at a national day speech in August, 2001, stating that the "China economy is potentially 10 times the size of Japan's. Just ask yourselves, how does Singapore compete against 10 post-war Japans all industrializing and exporting at the same time?" (Panitchpakdi \& Clifford, 2002, p. 103). Other countries in Asia shared this sentiment: "What if China is the world's lowest-cost producer of everything," (Panitchpakdi \& Clifford, 2002, p. 103). Even Ross Perot, US Presidential candidate, during his election campaign in 1992, labeled China as a "giant sucking sound" (Lo, 2003, p. 59).

The accession of China to the WTO in 2001 had integrated China into the world economy. As estimated by the World Bank, China's entry into WTO will increase its exports share in the world's total exports by about $10 \%$ by 2020, second after the US, and above Japan. In terms of GDP expansion, China will contribute $8 \%$ of global output by 2020, right after US, which will contribute about 19\% (Panitchpakdi \& Clifford, 2002). China is poised to be the world's second largest economy by 2020. The accession to the WTO and rising competition will possibly strengthen China's competitive power and restrain other Asian countries' price competitiveness further (Lo, 2003). Rapid industrial development, including trade expansion in China, particularly in export-oriented industries (EOIs) (Greenaway, Mahabir, \& Milner, 2008), will in some way affect the growth of ASEAN economies. The majority of EOIbased products are mainly electrical and electronics (E\&E) goods. Most of these goods belong to high and semi-technology industries that are capital intensive. E\&E industries are no longer regarded as labour-intensive, even though the number of workers employed in the industries is high compared to other types of industries such as textiles and consumer non-durable goods. For the expansion of EOIs, ASEAN needs and depends on FDI. The E\&E goods and transport equipment contributed to a large share of the total exports of China (Yao, 2008). In 2015, the E\&E products sector comprised more than 35\% of total exports and is a sector largely dominated by foreign firms (Zhao \& Jiang, 2009).

From 1995 to 2015, trade between ASEAN and China grew approximately $20 \%$ on the average. ASEAN total trade to China has increased from $2.2 \%$ in 1995 to $12.0 \%$ in 2010 and to $16.8 \%$ in 2015 . Trading with China 
favours China. Before ACFTA was signed, trade deficits were $\$ 0.9$ billion in 1995 and $\$ 3.9$ billion in 2000. The deficits worsened after ACFTA was implemented where in 2010 the deficits were $\$ 13.4$ billion, soaring to $\$ 87.3$

Table 2: ASEAN International Trade in the World and with China (\$'bil)

\begin{tabular}{|c|c|c|c|c|c|c|c|c|c|}
\hline & 1995 & 2000 & 2005 & 2010 & 2011 & 2012 & 2013 & 2014 & 2015 \\
\hline \multicolumn{10}{|c|}{ ASEAN - World } \\
\hline Export & 296.7 & 410.2 & 648.2 & $1,051.8$ & $1,244.6$ & $1,254.6$ & $1,273.9$ & $1,309.6$ & $1,189.8$ \\
\hline Import & 318.6 & 349.0 & 576.8 & 951.6 & $1,156.2$ & $1,226.3$ & $1,252.2$ & $1,249.0$ & $1,124.3$ \\
\hline $\begin{array}{l}\text { Total } \\
\text { Trade }\end{array}$ & 615.3 & 759.1 & $1,224.9$ & 2003.4 & 2400.8 & $2,480.9$ & $2,526.1$ & $2,558.5$ & $2,314.0$ \\
\hline \multicolumn{10}{|c|}{ ASEAN - China } \\
\hline Export & 6.2 & 14.2 & 52.3 & 113.8 & 143.7 & 142.8 & 153.5 & 163.2 & 151.0 \\
\hline Import & 7.1 & 18.1 & 61.1 & 127.2 & 158.2 & 180.6 & 202.9 & 221.8 & 238.3 \\
\hline $\begin{array}{l}\text { Total } \\
\text { Trade }\end{array}$ & 13.3 & 32.3 & 113.4 & 240.9 & 302.0 & 323.4 & 356.4 & 385.0 & 389.4 \\
\hline $\begin{array}{l}\text { Trade } \\
\text { balance }\end{array}$ & -0.9 & -3.9 & -8.8 & -13.4 & -14.5 & -37.8 & -49.4 & -58.6 & -87.3 \\
\hline \multicolumn{10}{|c|}{ Share of China $(\%)$} \\
\hline Export & 2.1 & 3.5 & 8.1 & 10.8 & 11.5 & 11.4 & 12.0 & 12.5 & 12.7 \\
\hline Import & 2.2 & 5.2 & 10.6 & 13.4 & 13.7 & 14.7 & 16.2 & 17.8 & 21.2 \\
\hline $\begin{array}{l}\text { Total } \\
\text { Trade }\end{array}$ & 2.2 & 4.3 & 9.3 & 12.0 & 12.6 & 13.0 & 14.1 & 15.0 & 16.8 \\
\hline
\end{tabular}

Source: Calculated by author, data from Trade Map (n.d.).

billion in 2015 (Table 2). China has become one of the major trade partners not only to ASEAN as a group but also to individual members of ASEAN. Under an upgraded agreement on ACFTA that was concluded in November 2015, ASEAN and China expect to raise bilateral trade to $\$ 1,000$ billion in 2020. For instance, China is the fourth largest trade partner for Malaysia and Singapore and the third for Thailand. ASEAN's trade with Japan and the US remains higher since both of the countries are major trade partners to all members of ASEAN.

\section{ACFTA and Indonesian Manufacturing Sector}

Based on the short discussion on trade presented above, the Free Trade Agreement with China will produce significant impacts on Indonesian 
domestic industrial sectors (Tei \& Mohamed Aslam, 2013). According to a majority of studies (official documents) conducted by members of ASEAN and China, the Free Trade Agreement would produce positive opportunities such as increases in trade since the agreement created a large market of more than 1.8 billion of combined market (Chandra, 2005; Vanzetti, Setyoko, Nguyen, \& Trewin , 2011; Nasrudin, Bonar M. Sinaga, Muhammad Firdaus, \& Dedi Walujadi, 2015). However, most of the governments involved in the agreement failed to get information from non-state actors such as manufactures, traders, and business associations or chambers. The Indonesian government realised that there are certain industries that would be affected by the ACFTA (Kompas, 2010). As stated in Chandra (2005), in the case of Indonesia the government official from the Bappenas was sceptical about the studies conducted by government offices that assessed the impacts of various free trade deals including ACFTA on the economy.

Due to the lack of transparency and limited involvement of non-state actors in assessing the impact of ACFTA on trade and business environments, the establishment of ACFTA has subsequently led to public debate in Indonesia (Tei \& Mohamed Aslam, 2013). Non-state actors question to what extent that ACFTA could provide good economic opportunities to local businesses and to what extent that the local industries could survive from the import of cheaper goods from China. The free trade deal with China would definitely generate a significant negative impact on certain Indonesian domestic industries (Chandra, 2005). For example, in the case of the furniture industry, China is far more able to offer products that are cheaper and of a higher quality than Indonesia (Chandra, 2005). Before the date of the ACFTA implementation industry trade associations particularly the Indonesian Chamber of Commerce and Industry (KADIN - Kamar Dagang Indonesia), had voiced to the government the impact of ACFTA on Indonesian businesses. In general, business associations and other pressure groups in the country remain sceptical about benefits of the ACFTA. The government had been facing intense pressure from local companies who were fearful that competitive imports from China would force closure of their businesses (Tei \& Mohamed Aslam, 2013). Some Indonesian business leaders complained that the government failed to consult them in the process of negotiating the Free Trade Agreement. Many sectors are already reeling from competition with low-cost Chinese clothes, toys and electronic goods that are often smuggled into Indonesia (Zain, 2011). According to Sofjan Wanandi, Chairman of the Indonesian Employers Association, opening the borders will further hurt local 
businesses: "We're totally unable to compete and we'll have to close our factories" (Hariharan, 2010).

About two weeks after the ACFTA was officially launched in January 2010, the government asked the ASEAN Secretariat/ Council to renegotiate tariff reductions on 228 categories in 11 manufacturing sectors: steel, iron, textiles, electronics, basic inorganic chemicals, petrochemicals, furniture, footwear, machinery, cosmetics, and herbal medicines (The Jakarta Post, 2010). In return, the government offered to accelerate implementation of tariff cuts on 153 tariff categories. But the Indonesian government has indicated that it will maximise usage of safeguard measures. Safeguard measures would be implemented as soon as $30 \%$ of the domestic market for any product is controlled by China (Kompas, 2011). Thus, the governments of Indonesia and China decided to proceed with the full implementation of the ACFTA. Renegotiation was considered much more costly because in addition to compensation, Indonesia will have to renegotiate with China and with other ASEAN countries (Kompas, 2011).

Local industry associations particularly the Indonesian Textile Association (API), the Indonesian Association of Iron and Steel Industries (IISIA) feared that their sectors would suffer unfavorable results due to ACFTA (AntaraNews, 2009). They believed that a Free Trade Agreement between ASEAN and China would likely threaten Indonesian textile, clothing, and steel producers when China dominates local market share. The two industries believed that they are the most likely candidates to experience a double competitive squeeze and great pressure due to intense competition from China (Tei \& Mohamed Aslam, 2013). Furthermore, the Indonesian Employers Association (Apindo) is a group comprised of Indonesian manufacturers that feels uneasy with ACFTA. Since the impacts of ACFTA on Indonesia's economy are real, workers are also against the ACFTA. The Apindo and the Indonesian Labor Union for Prosperity (KSBSI) organized a National Bipartite Forum and demanded that the government take another look at the ACFTA and if possible delay the implementation of ACFTA in Indonesia (Mustaqim Adamrah, 2010). Imports data for January 2010 clearly reveal that since the implementation of ACFTA, there has been a surge of imports from China into the Indonesian market without import duties, including no charges for steel and textile and clothing (T\&C) products. The imports accounted for $83 \%$ of 8,738 imports (Ocean, 2010).

There were many reports on losses and closures of local companies due to the inability of the firms to compete with cheap Chinese products (Zain, 2011). The huge influx of imported Chinese products such as textiles, 
garments, footwear, electronics, toys, furniture, steel, chemicals, and machinery into the Indonesian markets has damaged a wide range of local manufactures and businesses (Zain, 2011). In the furniture industry, Indonesian exports show significant improvements from \$1.4 billion in 2002 to $\$ 1.6$ billion in 2004, but the Indonesian furniture market is still controlled by the import of furniture from China (Chandra, 2005). The local textile and clothing sector was severely damaged by the ACFTA. The Indonesian Employers Association (Apindo), stressed that approximately 7.5 million workers (about a quarter of the country's 30 million strong formal sector workforce) could lose their jobs (Hariharan, 2010).

The textile and clothing industry in Indonesia plays an important role in economic growth and development. The industry is the second largest export earner after the oil and gas sector. Clothing and textiles is a strategic industrial sector and the industry has grown from being a small subsector to a major contributor to the Indonesian economy over the last three decades (Tei \& Mohamed Aslam, 2013). The textile and clothing industry in Indonesia is ranked as the fourth biggest textile and clothing industry in the world (Hassen Saheed, 2006). Perhaps because of the lack of tariff protections, Indonesia is currently attempting to renegotiate its highly sensitive list with China. However, if items are to be included in the list others must be removed. This creates an inevitable trade-off among Indonesian domestic producers and China (Vanzetti et al., 2011).

Based on the data from the Indonesia Textiles and Clothing Reports in 2009, the export growth of textiles and clothing that averaged $13.9 \%$ in 2008 will decline to $7.6 \%$ in 2013 (Linda Yulisman, 2015). In July 2015 the government planned to raise import tariffs on a broad array of consumer goods ranging from coffee to cars and clothing with an import tariff on clothing ranging from $15-20 \%$ depending upon the garment type. The tariff rate increase seems to have provided no relief to the local textile industry that had suffered in early 2015 as raw materials purchased in USD become more expensive due to a weakening Rupiah (IDR). In early 2015, the Indonesian Textile Association reported that 18 firms in Java closed down and about 30,000 workers lost their jobs (Linda Yulisman, 2015). The reduction in exports indirectly affected employment in the industry. There were estimates that as many as 2.5 million workers in the labour-intensive leather and clothing factories and agribusiness industries could lose their jobs because their firms cannot outperform China rivals. For the worst-case scenario, a budget of more than IDR1 trillion has been prepared in order to fund employees for termination claims (Lim \& Kauppert, 2010). Therefore, banks will be more 
cautions and reluctant in lending to the textile and clothing industry because the industry will became riskier in the long term. In a longer period, i.e. after the implementation of the ACFTA, the textile and clothing industry may hurtle forward to secure funding from the financial institution (Ardian Wibisono, 2010). A lesser number of or no loans from financial institutions means that growth and expansion will be retarded.

The agricultural sector has also been hit by the ACFTA. Although Indonesia maintains relatively high tariffs on certain agricultural commodities such as rice, meat, sugar, and several types of fruits and vegetables, the Indonesian government has more or less agreed to introduce tariff reduction measures to the agricultural sector. Despite its relatively high tariff level on rice approximately $30 \%$ for example, Indonesia has become one of the major rice importers in the world. Trade liberalisation under FTAs has undermined the Indonesian food industry.

\section{Tariff Profiles: Indonesia versus China}

Table 3: China and Indonesia: Tariffs Rates

\begin{tabular}{|c|c|c|c|c|}
\hline & \multicolumn{2}{|c|}{ China } & \multicolumn{2}{c|}{ Indonesia } \\
\hline & $\begin{array}{c}\text { Average of } \\
\text { MFN tariffs }\end{array}$ & $\begin{array}{c}\text { Average of } \\
\text { preferential } \\
\text { tariffs }\end{array}$ & $\begin{array}{c}\text { Average of } \\
\text { MFN tariffs }\end{array}$ & $\begin{array}{c}\text { Average of } \\
\text { preferential } \\
\text { tariffs }\end{array}$ \\
\hline 2000 & $18.6 \%$ & $18.6 \%$ & $5.6 \%$ & $5.6 \%$ \\
\hline 2001 & $15.6 \%$ & $15.6 \%$ & $4.6 \%$ & $4.5 \%$ \\
\hline 2002 & na & na & $4.9 \%$ & $4.8 \%$ \\
\hline 2003 & $9.4 \%$ & $9.4 \%$ & $4.9 \%$ & $4.8 \%$ \\
\hline 2004 & $8.5 \%$ & $8.5 \%$ & $5.2 \%$ & $5.1 \%$ \\
\hline 2005 & na & na & $5.2 \%$ & $5.1 \%$ \\
\hline 2006 & $7.5 \%$ & $7.4 \%$ & $5.2 \%$ & $5.1 \%$ \\
\hline 2007 & $11.9 \%$ & $11.7 \%$ & $4.3 \%$ & $4.2 \%$ \\
\hline 2009 & $11.5 \%$ & $11.1 \%$ & $4.1 \%$ & $4.0 \%$ \\
\hline 2010 & $12.2 \%$ & $11.7 \%$ & $4.8 \%$ & $4.6 \%$ \\
\hline 2011 & $12.0 \%$ & $11.6 \%$ & $4.8 \%$ & $4.6 \%$ \\
\hline 2013 & na & na $\%$ & $4.7 \%$ & $4.5 \%$ \\
\hline 2014 & $12.2 \%$ & $11.0 \%$ & na & na \\
\hline 2015 & $12.3 \%$ & $11.0 \%$ & na & na \\
\hline 2016 & $12.4 \%$ & $10.9 \%$ & na & na \\
\hline
\end{tabular}

Source: Trade Map (n.d.). 
Tariff and non-tariff barriers (NTB) are crude measurements of trade liberalisation and indicator competitiveness of any particular country. Looking at Table 3, Indonesia's most favoured nation (MFN) tariff rates on average have declined from $5.6 \%$ in 2000 to $4.7 \%$ in 2013, while the average preferential tariffs rate offered by Indonesia also declined from $5.6 \%$ to $4.5 \%$ respectively. The decline in preferential tariff rates is probably related to the tariff concession that was given to members of ASEAN under the ASEAN Free Trade Area (AFTA) programme. The Indonesian economy has been relatively open since the economic crisis of 1997. Indonesian trade and investment policies are in-line with the government's commitment to global trade liberalisation. The government commitment to the Uruguay Round, a multilateral trade agreement that was signed in 1994, and the ASEAN Free Trade Area (AFTA) have generally lowered the tariff levels for domestic manufacturing and agriculture sectors.

Table 4: Indonesia and China: Tariff Profiles by Product Group

\begin{tabular}{|c|c|c|c|c|c|c|c|c|}
\hline & \multicolumn{4}{|c|}{ China } & \multicolumn{4}{|c|}{ Indonesia } \\
\hline & \multicolumn{2}{|c|}{ Agriculture } & \multicolumn{2}{|c|}{ Non-Agriculture } & \multicolumn{2}{|c|}{ Agriculture } & \multicolumn{2}{|c|}{ Non-Agriculture } \\
\hline & $\begin{array}{l}\text { Average } \\
\text { of MFN } \\
\text { tariffs }\end{array}$ & $\begin{array}{l}\text { Average of } \\
\text { preferential } \\
\text { tariffs }\end{array}$ & $\begin{array}{l}\text { Average } \\
\text { of MFN } \\
\text { tariffs }\end{array}$ & $\begin{array}{l}\text { Average of } \\
\text { preferential } \\
\text { tariffs }\end{array}$ & $\begin{array}{l}\text { Average } \\
\text { of MFN } \\
\text { tariffs }\end{array}$ & $\begin{array}{l}\text { Average } \\
\text { of } \\
\text { preferent } \\
\text { ial tariffs }\end{array}$ & $\begin{array}{l}\text { Average of } \\
\text { MFN tariffs }\end{array}$ & $\begin{array}{l}\text { Avera } \\
\text { ge of } \\
\text { prefer } \\
\text { ential } \\
\text { tariffs }\end{array}$ \\
\hline 2000 & $24.7 \%$ & na & $18.1 \%$ & na & $12.2 \%$ & na & $5.2 \%$ & na \\
\hline 2001 & $27.9 \%$ & na & $14.7 \%$ & na & $12.6 \%$ & na & $4.1 \%$ & na \\
\hline 2002 & na & na & na & na & $12.7 \%$ & na & $4.4 \%$ & na \\
\hline 2003 & $20.1 \%$ & na & $8.7 \%$ & na & $12.3 \%$ & na & $4.5 \%$ & na \\
\hline 2004 & $18.0 \%$ & na & $7.8 \%$ & na & $12.5 \%$ & na & $4.8 \%$ & na \\
\hline 2005 & na & na & na & na & $13.6 \%$ & $13.5 \%$ & $4.7 \%$ & $4.6 \%$ \\
\hline 2006 & $16.0 \%$ & $15.7 \%$ & $6.9 \%$ & $6.8 \%$ & $13.5 \%$ & $13.4 \%$ & $4.7 \%$ & $4.6 \%$ \\
\hline 2007 & $22.6 \%$ & $22.2 \%$ & $11.1 \%$ & $10.9 \%$ & $13.3 \%$ & $13.2 \%$ & $3.7 \%$ & $3.6 \%$ \\
\hline 2009 & $22.2 \%$ & $21.6 \%$ & $10.7 \%$ & $10.4 \%$ & $12.9 \%$ & $12.7 \%$ & $3.5 \%$ & $3.4 \%$ \\
\hline 2010 & $23.2 \%$ & $22.4 \%$ & $11.4 \%$ & $10.9 \%$ & $13.2 \%$ & $12.9 \%$ & $4.2 \%$ & $4.0 \%$ \\
\hline 2011 & $22.6 \%$ & $22.0 \%$ & $11.2 \%$ & $10.9 \%$ & $13.6 \%$ & $13.4 \%$ & $4.2 \%$ & $4.0 \%$ \\
\hline 2013 & na & na & na & na & $11.9 \%$ & $11.7 \%$ & $4.2 \%$ & $4.0 \%$ \\
\hline 2014 & $22.6 \%$ & $19.9 \%$ & $11.5 \%$ & $10.3 \%$ & na & na & na & na \\
\hline 2015 & $22.6 \%$ & $19.8 \%$ & $11.6 \%$ & $10.3 \%$ & na & na & na & na \\
\hline 2016 & $22.9 \%$ & $19.9 \%$ & $11.6 \%$ & $10.2 \%$ & na & na & na & na \\
\hline
\end{tabular}

Source: Trade Map (n.d.). 
In contrast, the tariff level in China is quite high compared to Indonesia. The average MFN tariff level in 2000 was $18.6 \%$ and approximately $12.4 \%$ in 2016. The preferential tariff that was offered by the Chinese government to FTA partners in 2000 was $18.6 \%$ and declined to $10.9 \%$ in 2016. Although China has been a member of the World Trade Organisation (WTO) since 2002, the commitment to liberalising trade is quite slow based on reported data as shown in the tables. This paper suggests that there are quite a number of goods or tariff lines by HS6 digits listed in the sensitive list. The Chinese government seems to be protecting some of the domestic industries wholly owned by local people or state enterprises.

Tariff by product group as depicted in Table 4 shows that tariff rates imposed by the Chinese government for agriculture products were quite high. MFN and preferential tariff rates for 2016 were $22.9 \%$ and $19.9 \%$ respectively. For non-agriculture products during 2016, the MFN rate was $11.6 \%$ while the preferential rate was $10.2 \%$.

The tariff rates offered by the Indonesian government for agriculture and non-agriculture products were much lower than China's rate. On average the MFN and preferential tariff rates for agriculture in 2013 were $11.9 \%$ and $11.7 \%$ respectively, while the non-agriculture MFN tariff rate in 2013 was $4.2 \%$ and the preferential tariff rate was $4.0 \%$. Based on Table 5 , the number of NTBs imposed by the Indonesian government on foreign goods was much lower than the number of NTBs imposed by the Chinese government. Both countries largely utilised Sanitary, Phytosanitary, and Technical Barriers to Trade on product in restricting the inflow of goods from certain countries.

Based on Tables 3, 4, and 5, Indonesia's trade policy seems to be more liberally welcoming than China's trade policy. Under the ACFTA and since tariffs on most goods were eliminated by 2010, this paper assumes that Chinese exporters enjoyed greater tariff-free access to the Indonesian market than Indonesian exporters accessing the Chinese market. Even though tariff eliminations under the ACFTA sought to further expand trade between the two countries (and to other members of ASEAN), a country would be facing a loss or trade diversion under ACFTA as mentioned earlier. In 2015, bilateral trade between China and Indonesia reached $\$ 44.5$ billion. The prior discussion above indicates a crucial question: Is Indonesia competitive enough to compete in the global economy, particularly in the ACFTA region? The Global Competitiveness Index (GCI) produced by the World Economic Forum shows that from 2011 to 2015 the GCI index score for Indonesia was lower than China's score (Table 6). Based on Table 6, China is more competitive than Indonesia. 
Table 5: Indonesia and China: Non-Tariff Narriers (NTB)

\begin{tabular}{|c|c|c|c|c|c|}
\hline NTB Types & & \multicolumn{2}{|c|}{ Indonesia } & \multicolumn{2}{|c|}{ China } \\
\hline & Phase & $\begin{array}{l}\text { HS } \\
\text { lines }\end{array}$ & Measures & $\begin{array}{l}\text { HS } \\
\text { lines }\end{array}$ & Measures \\
\hline Export Subsidies & In force & 1 & 1 & 0 & 0 \\
\hline Safeguards & In force & 5 & 5 & 0 & 0 \\
\hline Safeguards & Initiation & 1 & 1 & 1 & 1 \\
\hline $\begin{array}{l}\text { Sanitary and } \\
\text { Phytosanitary }\end{array}$ & In force & 21 & 48 & 19 & 118 \\
\hline $\begin{array}{l}\text { Sanitary and } \\
\text { Phytosanitary }\end{array}$ & Initiation & 41 & 55 & 354 & 902 \\
\hline Tariff-rate quotas & In force & 2 & 2 & 10 & 10 \\
\hline $\begin{array}{l}\text { Technical Barriers to } \\
\text { Trade }\end{array}$ & In force & 15 & 22 & 72 & 98 \\
\hline $\begin{array}{l}\text { Technical Barriers to } \\
\text { Trade }\end{array}$ & Initiation & 49 & 89 & 486 & 1,067 \\
\hline Anti dumping & In force & 33 & 33 & 75 & 90 \\
\hline Anti dumping & Initiation & 15 & 15 & 11 & 11 \\
\hline Countervailing & inforce & 0 & 0 & 4 & 4 \\
\hline $\begin{array}{l}\text { Quantitative } \\
\text { Restrictions }\end{array}$ & inforce & 0 & 0 & 21 & 21 \\
\hline
\end{tabular}

Source: World Trade Organisation (n.d.).

Table 6: Global Competitiveness Index (GCI): Indonesia and China

\begin{tabular}{|l|c|c|c|c|}
\hline & \multicolumn{2}{|c|}{ Indonesia } & \multicolumn{2}{c|}{ China } \\
\hline & $\begin{array}{c}\text { Rank } \\
\text { (out of } \\
144)\end{array}$ & $\begin{array}{c}\text { Score } \\
(1-7)\end{array}$ & $\begin{array}{c}\text { Rank } \\
\text { (out of } \\
144)\end{array}$ & $\begin{array}{c}\text { Score } \\
(1-7)\end{array}$ \\
\hline GCI 2014-2015 & 34 & 4.6 & 28 & 4.9 \\
\hline GCI 2013-2014 (out of 148) & 38 & 4.5 & 29 & 4.8 \\
\hline GCI 2012-2013 (out of 144) & 50 & 4.4 & 29 & 4.8 \\
\hline GCI 2011-2012 (out of 142) & 46 & 4.4 & 26 & 4.9 \\
\hline & & & & \\
\hline Basic requirements (40.0\%) & 46 & 4.9 & 28 & 5.3 \\
\hline Efficiency enhancers (50.0\% & 46 & 4.4 & 30 & 4.7 \\
\hline $\begin{array}{l}\text { Innovation \& sophistication factors } \\
(10 \%)\end{array}$ & 30 & 4.2 & 33 & 4.1 \\
\hline
\end{tabular}

Source: The global competitiveness report 2014-2015 (2014). 


\section{Methodology and Data}

In looking at the impact of the ACFTA on Indonesian manufacturing industries, this paper calculates and utilises trade performance indices. To a certain extent, calculations of trade performance indices are able to show the level of competitiveness or incompetitiveness of certain manufacturing industries. The trade performance indices that will be used are the intraindustry trade (IIT) index, the revealed comparative index (RCA), and the Hillman index. The methodology of the indices are as follows:

\section{Intra-industry Trade Index}

The paper uses a standard (simple) Intra-industry trade index (IIT) formula proposed by Grubel and Lloyd (1975). Grubel and Lloyd's work has been used in numerous studies such as for calculating trade or industry competitiveness or looking at an export sector or manufacturing as inward or external looking. The formula for the IIT index is given by the following equation:

$\mathrm{IIT}=1-\{(\mathrm{X}+\mathrm{M})-(|\mathrm{X}-\mathrm{M}|) /(\mathrm{X}+\mathrm{M})\}$

Where $(X+M)$ is the value of gross trade and $|X-M|$ is the absolute value of inter-industry trade, while the numerator of the equation measures intraindustry trade as the net value of total trade remaining after net exports, or net imports are subtracted. The net value of total trade is given in the form of a proportion of the value of total trade. The main intention of applying IIT to see if there is an intra-industry link between Indonesian and China by manufacturing industries classification.

\section{Revealed Comparative Index (RCA)}

For the RCA index this paper uses Balassa's version of the BRCA formula. The formula is as follows:

$$
\operatorname{BRCA}=\left(X_{i j} / X_{i t}\right) /\left(X_{n j} / X_{n t}\right)
$$

Where $X$ is exports, subscript $i$ is a country, $j$ is a commodity or industry, $t$ is a set of commodities (or industries) and $n$ is a set of countries. BRCA estimates a country's exports of a commodity (or industry) relative to its total exports and to the corresponding exports of a set of countries. The BRCA index takes a value between 0 and $+\infty$. A country is said to have a revealed comparative (competitive) advantage if the value exceeds unity. If BRCA is less than unity, 
the country is said to have a comparative (or competitive) disadvantage in the commodity or product or industry. Hinloopen and Marrewijk (2001) have divided the theoretical range of the BRCA value into four classes as shown in Table 7. Widely criterion is used if a good sector or production sector has a value of $B R C A>1$, so we assume that sector or industry has a comparative advantage. But a sector or industry can be classified as or contain high comparative advantage. Therefore, the rationale of dividing the BRCA into four classes as indicated in Table 7, is to look for and distinguish which sector or industry shows or gains high comparative advantage, and vice-versa.

This study has modified the BRCA formula to look at two or three other aspects: (i) the level of Indonesia's competitive advantage in the world; (ii) the level of Indonesia's competitive advantage region, i.e., ACFTA (Regional); and (iii) the degree of competition in China market vis-à-vis ASEAN. For China the RCA index is also calculated in respect to the World and by Region.

Table 7: BRCA Classifications

\begin{tabular}{|l|l|l|}
\hline Class a & $0<\mathrm{RCA}<1$ & Industries with a comparative disadvantage \\
\hline Class $\mathrm{b}$ & $1<\mathrm{RCA}<2$ & Industries with weak comparative disadvantage \\
\hline Class $\mathrm{c}$ & $2<\mathrm{RCA}<4$ & Medium comparative advantage \\
\hline Class $\mathrm{d}$ & $4<\mathrm{RCA}$ & Strong comparative advantage \\
\hline
\end{tabular}

\section{Hillman Index}

In addition to the relevance of Balassa's RCA index in dictating comparative advantage (Hinloopen \& Marrewijk, 2008) as mentioned above, the index contains a few important elements. These important elements were dictated by Hillman (1980) as conditions for comparative advantage. Hillman examines the relationship between the Balassa index (BRCA and pre-trade relative prices in cross-country comparisons for a specific sector under homothetic preferences by forming a Hicksian composite commodity for all other sectors (Hinloopen \& Marrewijk, 2008; Ferto \& Hubbard, 2003). As the concomitant transformation of the Balassa index has to be monotonic, Hillman's condition can be interpreted as a monotonicity condition for scaling a country's exports by a measure of its (sector) size index or condition. The Hillman condition can be summarized by the following equation:

Hillman condition $=\left\{1-\mathrm{X}_{\mathrm{ij}} / \mathrm{W}_{\mathrm{i}}\right\}>\left\{\mathrm{X}_{\mathrm{ij}} / \mathrm{X}_{\mathrm{j}}\left(1-\mathrm{X}_{\mathrm{j}} / \mathrm{W}\right)\right\}$

Where $X_{i j}$ is exports of commodity $i$ by country $j, X_{j}$ is total exports of country $j$, $W_{i}$ is world exports of commodity $I$, and $W$ is the world's total exports. 
According to Hinloopen and Marrewijk (2005) Hillman's condition equation as given above must be met for the value of the Balassa index given as BRCA, to be in concordance with pre-trade relative prices, that is, to ensure that the Balassa index increases if $\mathrm{X}_{\mathrm{ij}}$ increases. The Hillman condition equation contains three main parts, all of which have a different economic explanation. The three combined are known as the Hillman condition (Hinloopen and Marrewijk, 2005), the major components of which can be described as follows:

(a) Market share, as measured by $\left(\mathrm{X}_{\mathrm{ij}} / \mathrm{W}_{\mathrm{i}}\right)$, is the share of a country's exports in a particular commodity, product or sector relative to the total exports in that commodity, product or sector of the reference group of countries (or world, W).

(b) Degree of specialisation, as measured by $\left(\mathrm{X}_{\mathrm{ij}} / \mathrm{X}_{\mathrm{i}}\right)$, is the share of a country's exports in a particular product, commodity or sector of total exports.

(c) Country size, as measured by $\left(X_{i} / W\right)$, is the share of a country's total exports relative to the total exports of the group of reference countries (or world, W).

The Hillman condition can be transformed into an index (Hillman, 1980). The equation of the Hillman condition or Hillman Index is given below (Marchese \& Simone, 1989).

Hillman index $=\left\{1-\mathrm{X}_{\mathrm{ij}} / \mathrm{W}_{\mathrm{i}}\right\} /\left\{\mathrm{X}_{\mathrm{ij}} / \mathrm{X}_{\mathrm{j}}\left(1-\mathrm{X}_{\mathrm{j}} / \mathrm{W}\right)\right\}$

As Hillman (1980) stated, violations of subject (b) degree of specialisation, occur in the case of a country which exports only one commodity or when a country is the sole supplier. In general, the Hillman conditions are violated if a country experiences a high proportion in the supply market of a particular product or commodity in the presence of a high degree of export specialisation. This might really be true in the case of a small country. The Hillman Index was constructed in the perfect world and country model $2 \times 2$. Theoretically, either one or both countries will have the index as below 1 and the countries would have violated the conditions of the Hillman index. In a world that has more than 150 countries it is quite impossible that all the countries will fulfill the Hillman conditions. On the other hand, the index indicates whether a country has a competitive advantage. If the calculated 
index approaches unity or less than 1 or the value is low compared with another country or product or industry, then we can say that the country has a competitive advantage. Papers utilised the Hillman index such as in Marchese and Nadal de Simone (1989), where they show that Hillman's condition is violated in less than $10 \%$ of exports for 118 developing countries in 1985 . The other study by Hinloopen and Van Marrewijk (2001) indicated that Hillman's condition was not valid for only $7 \%$ of export value and less than $1 \%$ of the number of observations.

In general, the Hillman index formula generated a large value and to a certain extent a value that is incomparable and difficult to interpret compared to BRCA. For an easy understanding this paper modified the Hillman Index formula as:

Hillman index $=\left[\left\{1-\mathrm{X}_{\mathrm{ij}} / \mathrm{W}_{\mathrm{i}}\right\} /\left\{\mathrm{X}_{\mathrm{ij}} / \mathrm{X}_{\mathrm{j}}\left(1-\mathrm{X}_{\mathrm{j}} / \mathrm{W}\right)\right\}\right] / 100$

To simplify, if the value of the index approaches 0.0 then the product or industry has a competitive advantage, and the product or industry is noncompetitive if the index has a large value or more than 1.0.

As in the case of BRCA, this paper also calculated Hillman index for three angles, i.e., competitive position in the world, regional (ACFTA), and competition position in the China market for Indonesia, while China's Hillman Index was only calculated for two aspects, the world and the regional.

Data for the analysis was collected from Trade Map (n.d.). Exports and imports data are quoted in Harmonised System 2 (HS2) digits classification, 99 lines of products. For this paper the data was then re-organised into category manufacturing industries (refer to Mohamed Aslam [2012]). Products that belong to raw material categories were omitted.

\section{Indonesia-China Trade}

Indonesia's manufacturing sector has expanded quite significantly since 1990. From 1990 to 2015 the sector contribution to GDP has increased more than $25 \%$. Based on the structure of production, Indonesia is still an agrarian country The sector absorbs approximately. The agriculture sector was the main economic and employment sector with quite a substantial amount of labour. $44 \%$ of total employment. However the agriculture sector's contribution to Indonesia's GDP has declined. The expansion of the manufacturing sector and services sector has reduced the contribution of the agriculture sector to GDP and to employment creation. Although the manufacturing sector has 
expanded contributions to employment creation increased marginally from 1990 to 2015. However, manufacturing remains one of the main sectors contributing to Indonesia's GDP growth.

Table 8: Indonesia: Exports to World and China (\%)

\begin{tabular}{|c|c|c|c|c|c|c|}
\hline Manufacturing Industry & 2001 & 2010 & 2015 & 2001 & 2010 & 2015 \\
\hline & \multicolumn{3}{|c|}{ World } & \multicolumn{3}{|c|}{ China } \\
\hline Food & 4.8 & 14.2 & 17.5 & 6.5 & 11.4 & 19.1 \\
\hline Beverages & 0.0 & 0.1 & 0.1 & 0.0 & 0.0 & 0.0 \\
\hline Tobacco products & 0.5 & 0.5 & 0.7 & 0.0 & 0.0 & 0.1 \\
\hline Textiles & 5.9 & 3.1 & 3.3 & 5.7 & 2.0 & 1.8 \\
\hline apparel & 12.1 & 6.7 & 9.1 & 0.4 & 0.4 & 0.7 \\
\hline Footwear & 0.8 & 0.3 & 0.3 & 0.1 & 0.2 & 0.1 \\
\hline Wood & 7.7 & 3.1 & 4.2 & 23.9 & 10.4 & 6.7 \\
\hline Paper & 3.9 & 2.9 & 2.6 & 7.2 & 2.7 & 1.4 \\
\hline Printing & 0.0 & 0.0 & 0.0 & 0.0 & 0.0 & 0.0 \\
\hline Petroleum & 27.7 & 32.6 & 25.1 & 29.4 & 43.6 & 43.3 \\
\hline chemicals & 3.5 & 3.5 & 3.6 & 10.1 & 10.1 & 6.9 \\
\hline Pharmaceutical & 0.1 & 0.2 & 0.4 & 0.0 & 0.0 & 0.0 \\
\hline Rubber & 2.4 & 6.5 & 4.3 & 3.5 & 5.4 & 10.2 \\
\hline Plastic & 2.0 & 1.5 & 1.6 & 4.7 & 1.6 & 1.6 \\
\hline Glass and non-metallic & 2.3 & 1.7 & 4.6 & 1.0 & 0.6 & 0.2 \\
\hline Basic iron and steel & 1.4 & 1.8 & 2.3 & 0.8 & 1.4 & 0.6 \\
\hline Non-ferrous metals & 2.3 & 5.1 & 3.0 & 1.2 & 4.3 & 2.5 \\
\hline Metal products & 0.2 & 0.2 & 0.2 & 0.1 & 2.4 & 1.0 \\
\hline General machinery & 5.3 & 3.5 & 3.8 & 1.1 & 2.3 & 2.9 \\
\hline Electrical \& electronics & 11.5 & 7.2 & 6.2 & 3.7 & 0.0 & 0.0 \\
\hline Scientific equipment & 1.0 & 0.7 & 0.8 & 0.1 & 0.1 & 0.2 \\
\hline Transport equipment & 1.1 & 2.9 & 4.3 & 0.1 & 0.7 & 0.4 \\
\hline Furniture & 2.8 & 1.4 & 1.3 & 0.2 & 0.2 & 0.1 \\
\hline Other Industries & 0.6 & 0.4 & 0.6 & 0.1 & 0.1 & 0.1 \\
\hline Total (US\$'billions) & 51.6 & 140.4 & 138.0 & 2.2 & 6.3 & 13.9 \\
\hline
\end{tabular}

Source: Calculated by author, data from Trade Map (n.d.).

The major manufacturing industries that contribute to Indonesian world exports are petroleum products, chemicals, rubber, food, electrical and electronics (E\&E), and textiles and apparel (T\&C) (Table 8). Certain industries' contributions have dropped even though the industries seem be significant to Indonesia. Such industries are E\&E, wood and related products, paper, and 
textiles. The main exports from Indonesia to China by manufacturing industries are manufactured products of wood, cork, straw and painting materials, manufactured petroleum products, paper and paper products, and manufactured clothing apparel except fur. High technology industries such as E\&E, machinery and transportation contributed less to Indonesian exports to China (Table 8). Contributions of textiles and apparel/garment exports to China have largely declined. Exports of textiles have declined from $5.7 \%$ to $1.8 \%$, whereas exports of garments have declined on an average of about $0.4 \%$. Contributions to exports via paper industries declined from $7.2 \%$ in 2001 to $1.4 \%$ in 2015 .

Table 9: Indonesia: Imports from World and China (\%)

\begin{tabular}{|c|c|c|c|c|c|c|}
\hline Manufacturing Industry & 2001 & 2010 & 2015 & 2001 & 2010 & 2015 \\
\hline & \multicolumn{3}{|c|}{ World } & \multicolumn{3}{|c|}{ China } \\
\hline Food & 7.2 & 6.3 & 8.0 & 5.5 & 2.1 & 1.6 \\
\hline Beverages & 0.1 & 0.1 & 0.1 & 0.0 & 0.0 & 0.0 \\
\hline Tobacco products & 0.7 & 0.4 & 0.3 & 4.5 & 1.0 & 0.7 \\
\hline Textiles & 7.8 & 3.8 & 4.5 & 7.1 & 6.6 & 7.2 \\
\hline apparel & 0.8 & 1.2 & 1.7 & 2.4 & 3.0 & 2.9 \\
\hline Footwear & 0.6 & 0.4 & 0.5 & 0.8 & 0.5 & 0.6 \\
\hline Wood & 2.8 & 1.5 & 1.2 & 0.6 & 0.4 & 0.3 \\
\hline Paper & 1.0 & 0.8 & 1.0 & 0.5 & 0.6 & 0.7 \\
\hline Printing & 0.1 & 0.0 & 0.1 & 0.0 & 0.0 & 0.0 \\
\hline Petroleum & 18.8 & 21.5 & 18.5 & 19.3 & 3.9 & 0.9 \\
\hline chemicals & 13.5 & 8.2 & 9.3 & 18.1 & 8.3 & 10.1 \\
\hline Pharmaceutical & 0.3 & 0.4 & 0.5 & 0.4 & 0.1 & 0.1 \\
\hline Rubber & 1.2 & 1.3 & 1.2 & 1.2 & 0.8 & 0.8 \\
\hline Plastic & 3.8 & 3.8 & 5.0 & 2.0 & 2.5 & 3.5 \\
\hline Glass and non-metallic & 0.6 & 0.7 & 1.3 & 1.9 & 1.4 & 2.0 \\
\hline Basic iron and steel & 5.7 & 7.7 & 7.4 & 5.5 & 8.0 & 11.0 \\
\hline Non-ferrous metals & 2.0 & 2.4 & 2.4 & 2.8 & 1.8 & 2.0 \\
\hline Metal products & 0.6 & 0.7 & 0.8 & 1.7 & 1.4 & 1.3 \\
\hline General Purpose machinery & 16.0 & 15.6 & 16.5 & 10.8 & 24.2 & 25.7 \\
\hline Electrical and electronics & 4.9 & 12.3 & 11.5 & 7.1 & 25.4 & 22.6 \\
\hline Scientific equipment & 1.2 & 1.5 & 1.6 & 0.9 & 1.4 & 1.3 \\
\hline Transport equipment & 9.9 & 8.8 & 5.5 & 5.3 & 4.2 & 2.4 \\
\hline Furniture & 0.1 & 0.3 & 0.5 & 0.2 & 0.9 & 1.3 \\
\hline Other Industries & 0.3 & 0.4 & 0.5 & 1.4 & 1.2 & 0.9 \\
\hline Total (US\$'billions) & 29.4 & 128.0 & 135.3 & 1.7 & 19.3 & 28.0 \\
\hline
\end{tabular}

Source: Calculated by author, data from Trade Map (n.d.). 
Table 10: Indonesia-China Trade Balance (US\$millions)

\begin{tabular}{|c|c|c|c|c|c|c|}
\hline Manufacturing Industry & 2001 & 2005 & 2010 & 2013 & 2014 & 2015 \\
\hline Food & 48 & 621 & 2245 & 2415 & 2603 & 2919 \\
\hline Beverages & 0 & 0 & -3 & 2 & 1 & 2 \\
\hline Tobacco products & -75 & -45 & -186 & -267 & -256 & -197 \\
\hline Textiles & 3 & -56 & -1018 & -1555 & -1573 & -1539 \\
\hline apparel & -30 & -57 & -476 & -526 & -419 & -315 \\
\hline Footwear & -12 & -9 & -90 & -150 & -145 & -127 \\
\hline Wood & 503 & 637 & 850 & 1722 & 1879 & 1863 \\
\hline Paper & 145 & 134 & 74 & -131 & -108 & -49 \\
\hline Printing & 0 & -5 & -3 & -7 & -6 & -8 \\
\hline Petroleum & 308 & 1456 & 5271 & 7935 & 5627 & 4257 \\
\hline chemicals & -87 & -5 & -630 & -1738 & -1936 & -2223 \\
\hline Pharmaceutical & -5 & -4 & -16 & -21 & -25 & -22 \\
\hline Rubber & 55 & 303 & 1267 & 1295 & 584 & 293 \\
\hline Plastic & 68 & 2 & -273 & -622 & -714 & -775 \\
\hline Glass and non-metallic & -10 & -72 & -243 & -453 & -512 & -535 \\
\hline Basic iron and steel & -74 & -770 & -1446 & -2537 & -2964 & -2771 \\
\hline Non-ferrous metals & -22 & 139 & -6 & -100 & -353 & -265 \\
\hline Metal products & -27 & -76 & -272 & -396 & -374 & -354 \\
\hline General purpose machinery & -156 & -731 & -4511 & -7069 & -7023 & -7082 \\
\hline Electrical and electronics & -40 & -388 & -4488 & -6400 & -6494 & -6003 \\
\hline Scientific equipment & -13 & -60 & -251 & -351 & -296 & -281 \\
\hline Transport equipment & -86 & -110 & -755 & -1010 & -860 & -602 \\
\hline Furniture & 1 & -38 & -162 & -333 & -323 & -337 \\
\hline Other Industries & -22 & -75 & -227 & -307 & -235 & -239 \\
\hline Total Trade Balance (+/-) & 470 & 789 & -5348 & $\begin{array}{r}- \\
10603\end{array}$ & $\begin{array}{r}- \\
13924\end{array}$ & -14391 \\
\hline
\end{tabular}

Source: Calculated by author, data from Trade Map (n.d.).

On the other hand, major products made by manufacturing industries around the world and that are imported by Indonesia are textiles, petroleum products, chemicals, general machinery, electrical and electronics (E\&E), and transportation equipment (Table 9). The main imports from China as reported in Table 9 are petroleum products, but importation of these products declined in 2014. Imports of chemicals also declined in 2015. Other major import items from China are general machinery that has increased two-fold in 2015. Electrical and electronics are about $23 \%$ of total imports from China. Textiles 
comprised approximately $7.2 \%$ of total imports from China in 2015 while imports of apparel were close to 3\% in 2015.

Indonesia experienced trade deficits in various product categories (Table 8 and Table 9). Table 8, Table 9 and Table 10 show that in general, trade with China puts Indonesia on the losing side. On the one hand, based on trade by manufacturing industries, Indonesia gained in the food, wood, petroleum, and rubber industries. But on the other hand, Indonesia incurred large deficits in the general machinery, E\&E, iron and steel, chemicals, and textiles industries. Based on the tables presented and the elaboration above, we can conclude that in trading with China, Indonesian manufacturers are unable to generate trade creation. Additionally, we can state implicitly that the ACFTA has not brought much assistance to Indonesia in terms of improving her trade performance in the region. Furthermore, the tables indirectly confirm that Indonesian trade more resembles primary sector dependence than manufacturing or technological dependence. This kind of trade relationship, i.e., exporting primary commodities, importing manufactured products has caused negative effect in the Indonesian trade sector. The impact of the 2008 global economic crisis that dented China's manufacturing industries had ultimately affected Indonesia's primary commodities sector. The decline in China's demands on Indonesia products reduced export revenues by nearly $5.8 \%$, the equivalent to $\$ 180$ billion from 2013-2014 (Pangestu, Rahardja, \& Ing, 2015).

Based on the above discussion and data presented in the tables, intratrade between Indonesia and China bear a resemblance to a resources-formanufacture pattern. Almost half of Indonesia's imports from China are machinery and electrical products. In 2010, exports of machinery and parts totaled approximately 13\% of total exports (Pangestu et al., 2015; Ando \& Kimura, 2013). Conversely, fuels, metals, wood, and vegetable products constituted three-quarters or $75 \%$ of Indonesia's exports to China, compared to $45 \%$ of its exports to the world. Indonesia is one main supplier of coal and liquefied natural gas to China's energy-intensive coastal areas. Indonesian raw materials and natural resource-commodity producers also enjoyed robust business since the ASEAN-China FTA pact took effect in January 2010. These producers exported more natural resource commodities to China for its economy that is hungry for raw materials for China's fast-growing manufacturing industry.

Based on absolute data of exports and imports of Indonesia to and from China it appears that complaints by KADIN and the textile and garment manufacturers' associations have a basis that their members are unable to 
compete with Chinese textiles and garment goods. For HS2 digit products, from 2001 to 2006 Indonesia had trade deficits in 69 out of 99 product lines. From 2010 to 2015, the number of Indonesian products lines with trade deficits increased to 80 , this number was calculated from the list of goods based on HS2 digits. The three major products by HS2 digits that favour Indonesia as gains in trading with China, reported in Table 11 are HS27; HS15 and HS47, while the three major products that Indonesia is losing trade competitiveness to China are HS84, HS85 and HS72.

Table 11: Indonesia-China Trade Balance: 10 Main Trading Products (Selected) (US\$million)

\begin{tabular}{|c|c|c|c|c|c|c|}
\hline HS 2 digit & 2001 & 2005 & 2010 & 2013 & 2014 & 2015 \\
\hline \multicolumn{7}{|c|}{ GAIN } \\
\hline 27 & 308 & 1,456 & 5,271 & 7,935 & 5,627 & 4,257 \\
\hline 15 & 112 & 671 & 2,443 & 2,475 & 2,685 & 2,929 \\
\hline 47 & 237 & 375 & 646 & 1,094 & 1,079 & 1,079 \\
\hline 44 & 266 & 262 & 206 & 629 & 801 & 785 \\
\hline 26 & 7 & 163 & 1,385 & 3,656 & 605 & 461 \\
\hline 40 & 55 & 303 & 1,267 & 1,295 & 584 & 293 \\
\hline 03 & 14 & 52 & -9 & 209 & 168 & 172 \\
\hline 74 & 15 & 220 & 256 & 222 & 176 & 141 \\
\hline 48 & 145 & 134 & 74 & -131 & -108 & -49 \\
\hline 29 & 111 & 351 & 174 & -354 & -364 & -675 \\
\hline \multicolumn{7}{|c|}{ LOSS } \\
\hline 84 & -156 & -731 & $-4,511$ & $-7,069$ & $-7,023$ & $-7,082$ \\
\hline 85 & -39 & -380 & $-4,464$ & $-6,379$ & $-6,473$ & $-5,982$ \\
\hline 72 & -36 & -503 & -666 & $-1,409$ & $-1,758$ & $-1,683$ \\
\hline 73 & -38 & -268 & -780 & $-1,128$ & $-1,206$ & $-1,088$ \\
\hline 28 & -131 & -194 & -336 & -543 & -536 & -424 \\
\hline 76 & -11 & -69 & -267 & -341 & -502 & -406 \\
\hline 87 & -56 & -76 & -329 & -559 & -478 & -405 \\
\hline 90 & -8 & -49 & -200 & -318 & -270 & -271 \\
\hline 69 & -14 & -53 & -107 & -204 & -266 & -247 \\
\hline 83 & -12 & -37 & -172 & -238 & -237 & -228 \\
\hline 89 & -31 & -33 & -315 & -414 & -320 & -176 \\
\hline 70 & 6 & -19 & -84 & -173 & -164 & -162 \\
\hline
\end{tabular}

Source: Calculated by author, data from Trade Map (n.d.).

HS 3- Fish, crustaceans, molluscs, aquatic invertebrates nes; HS15Animal,vegetable fats and oils, cleavage products, etc.; HS26- Ores, slag and ash; 
HS27- Mineral fuels, oils, distillation products, etc.; HS40- Rubber and articles thereof; HS44- Wood and articles of wood, wood charcoal; HS47- Pulp of wood, fibrous cellulosic material, waste, etc.; HS48- Paper \& paperboard, articles of pulp, paper and board; HS69- Ceramic products; HS72- Iron and steel; HS73- Articles of iron or steel; HS74- Copper and articles thereof; HS76- Aluminium and articles thereof; HS83- Miscellaneous articles of base metal; HS84- Nuclear reactors, boilers, machinery, etc.; HS85- Electrical, electronic equipment; HS87- Vehicles other than railway, tramway; HS90- Optical, photo, technical, medical, etc. apparatus.

\section{Intra-Industry Trade Index}

Table 12: Intra-Industry Trade: ASEAN-China and Indonesia-China

\begin{tabular}{|c|c|c|c|c|c|c|}
\hline & \multicolumn{3}{|c|}{ Indonesia-China } & \multicolumn{3}{|c|}{ ASEAN-China } \\
\hline Manufacturing Industry & 2001 & 2010 & 2015 & 2001 & 2010 & 2014 \\
\hline Food & 0.79 & 0.27 & 0.26 & 0.83 & 0.57 & 0.72 \\
\hline Beverages & 0.35 & 0.66 & 0.25 & 0.49 & 0.19 & 0.46 \\
\hline Tobacco products & 0.01 & 0.07 & 0.06 & 0.04 & 0.66 & 0.63 \\
\hline Textiles & 0.99 & 0.33 & 0.35 & 0.59 & 0.32 & 0.32 \\
\hline apparel & 0.39 & 0.30 & 0.54 & 0.06 & 0.12 & 0.14 \\
\hline Footwear & 0.28 & 0.23 & 0.25 & 0.79 & 0.62 & 0.42 \\
\hline Wood & 0.04 & 0.15 & 0.09 & 0.14 & 0.55 & 0.58 \\
\hline Paper & 0.11 & 0.76 & 0.61 & 0.59 & 0.23 & 0.11 \\
\hline Printing & 0.81 & 0.05 & 0.07 & 0.98 & 0.89 & 0.47 \\
\hline Petroleum & 0.68 & 0.22 & 0.07 & 0.60 & 0.64 & 0.75 \\
\hline chemicals & 0.83 & 0.75 & 0.52 & 0.96 & 0.97 & 0.94 \\
\hline Pharmaceutical & 0.19 & 0.14 & 0.12 & 0.33 & 0.12 & 0.09 \\
\hline Rubber & 0.43 & 0.19 & 0.28 & 0.30 & 0.21 & 0.30 \\
\hline Plastic & 0.50 & 0.61 & 0.54 & 0.21 & 0.50 & 0.77 \\
\hline Glass \& non-metallic & 0.81 & 0.21 & 0.08 & 0.64 & 0.49 & 0.36 \\
\hline Basic iron and steel & 0.31 & 0.11 & 0.04 & 0.58 & 0.16 & 0.11 \\
\hline Non-ferrous metals & 0.69 & 0.97 & 0.89 & 0.86 & 0.83 & 0.54 \\
\hline Metal products & 0.08 & 0.02 & 0.02 & 0.22 & 0.12 & 0.06 \\
\hline General machinery & 0.23 & 0.06 & 0.03 & 0.86 & 0.93 & 0.83 \\
\hline Electrical \& electronics & 0.78 & 0.15 & 0.11 & 0.80 & 0.62 & 0.79 \\
\hline Scientific equipment & 0.19 & 0.16 & 0.31 & 0.98 & 0.73 & 0.80 \\
\hline Transport equipment & 0.06 & 0.13 & 0.09 & 0.13 & 0.25 & 0.33 \\
\hline Furniture & 0.85 & 0.19 & 0.14 & 0.29 & 0.13 & 0.13 \\
\hline Other Industries & 0.09 & 0.08 & 0.15 & 0.13 & 0.19 & 0.14 \\
\hline
\end{tabular}


In general, the structure of IIT Indonesia-China seems to parallel the ratio of Indonesia's exports to China as well as ASEAN total exports to China. By manufacturing industries as shown in Table 12, high values of IIT are indicated in the industries of plastic, apparel and petroleum products. However the value of IIT for these industries have declined quite significantly from 2005 to 2015, while the IIT values of textiles, electrical, and electronics are decreasing. Manufacturers of non-ferrous metal have recorded a higher IIT index compared to the remainder of industries. Based on Table 8 and 9, it seems that most of the manufacturing industries are concentrating on the domestic market rather than exporting to foreign markets. Although the absolute value of Indonesia-China trade favours China, most of the products were either traded with other countries or production and sales were concentrated in the domestic market.

Contrastingly, the picture of IIT index by manufacturing industries for ASEAN is roughly not much different from Indonesia as shown in Table 12. ASEAN has a high value of IIT in the chemicals industry. Industries that have an IIT value range of 0.7 to 0.9 are non-ferrous metal, scientific equipment, electrical, and electronics. Industries that have IIT values ranging from 0.5 to 0.7 are food, wood, and petroleum. For most of the industries mentioned here, the value of IIT was high before 2005. However, since 2010 index values of these industries have declined significantly.

\section{Revealed Comparative Advantage (RCA) Index}

Based on RCA index by manufacturing industries, Indonesia has a comparative advantage in the world in the food and tobacco product industries with a trend of the index increasing. For manufactured products of wood, cork, straw, rubber, and petroleum, even though Indonesia has a comparative advantage the index trend is declining. For the industries of clothing apparel, except fur, and for the manufacture of textiles, Indonesia has a comparative advantage with an RCA index trend that seems to be stable. In the case of manufacturing petroleum products, Indonesia has a comparative advantage but the calculated RCA index value is decreasing (Table 13). These results somehow confirm what has been suggested by Setyari, Widodo, and Purnawan (2015), that Indonesia has a strong comparative advantage in the wood industry while the textile and garments sector's competitiveness declined. As for Indonesia's position in the regional market (ASEAN+China+Indonesia), the structure of the RCA index is slightly different (Table 13). Based on Table 13, Indonesia has a comparative advantage in food and petroleum products industries with the trend of RCA indices increasing; 
for industries of wood, cork, straw and plaiting materials the trend of RCA index is mixed or volatile; for the manufacturing industries of paper and paper products, non-ferrous metals and rubber products, RCA index trends are decreasing.

Table 13: Indonesia RCA Index: World and Regional

\begin{tabular}{|l|c|c|c|c|c|c|}
\hline & \multicolumn{3}{|c|}{ World } & \multicolumn{3}{c|}{ Regional } \\
\hline Manufacturing Industry & $\mathbf{2 0 0 1}$ & $\mathbf{2 0 1 0}$ & $\mathbf{2 0 1 5}$ & $\mathbf{2 0 0 1}$ & $\mathbf{2 0 1 0}$ & $\mathbf{2 0 1 5}$ \\
\hline Food & $\mathbf{1 . 3 2}$ & 3.44 & 3.87 & 1.58 & 4.40 & 5.30 \\
\hline Beverages & 0.07 & 0.08 & 0.14 & 0.50 & 0.42 & 0.66 \\
\hline Tobacco products & 1.42 & 1.88 & 2.73 & 4.61 & 4.66 & 6.96 \\
\hline Textiles & 2.32 & 1.93 & 2.14 & 1.56 & 0.69 & 0.99 \\
\hline apparel & 2.48 & 1.73 & 1.96 & 0.16 & 0.10 & 0.26 \\
\hline Footwear & 0.85 & 0.40 & 0.41 & 0.14 & 0.19 & 0.21 \\
\hline Wood & 5.06 & 2.79 & 3.66 & 4.25 & 2.67 & 5.31 \\
\hline Paper & 2.18 & 2.38 & 2.50 & 6.37 & 3.74 & 2.93 \\
\hline Printing & 0.10 & 0.11 & 0.10 & 0.08 & 0.06 & 0.21 \\
\hline Petroleum & 2.60 & 1.95 & 2.03 & 2.80 & 5.23 & 7.60 \\
\hline chemicals & 0.64 & 0.62 & 0.68 & 2.24 & 1.38 & 1.25 \\
\hline Pharmaceutical & 0.07 & 0.07 & 0.13 & 0.82 & 0.39 & 1.18 \\
\hline Rubber & 2.46 & 5.37 & 3.89 & 1.50 & 2.45 & 1.49 \\
\hline Plastic & 0.59 & 0.43 & 0.45 & 1.08 & 0.66 & 0.65 \\
\hline Glass and non-metallic & 0.72 & 0.40 & 0.89 & 1.64 & 0.64 & 1.11 \\
\hline Basic iron and steel & 0.39 & 0.39 & 0.58 & 1.22 & 0.60 & 0.55 \\
\hline Non-ferrous metals & 1.11 & 1.95 & 1.32 & 3.28 & 4.73 & 3.26 \\
\hline Metal products & 0.22 & 0.25 & 0.19 & 0.24 & 0.39 & 0.16 \\
\hline General machinery & 0.33 & 0.27 & 0.30 & 0.75 & 0.30 & 0.33 \\
\hline Electrical and electronics & 0.73 & 0.51 & 0.40 & 0.64 & 0.32 & 0.25 \\
\hline Scientific equipment & 0.27 & 0.19 & 0.20 & 0.29 & 0.24 & 0.19 \\
\hline Transport equipment & 0.08 & 0.27 & 0.35 & 0.94 & 1.13 & 1.33 \\
\hline Furniture & 2.04 & 1.17 & 0.83 & 0.37 & 0.11 & 0.11 \\
\hline Other Industries & 0.59 & 0.53 & 0.64 & 0.08 & 0.09 & 0.22 \\
\hline
\end{tabular}

Among members of ASEAN competing for China's market, Indonesia has gained a competitive advantage in similar industries as mentioned above (Table 14). By looking at the RCA index by manufacturing industry it appears that Indonesia has a competitive advantage in primary industries, industries that are associated with the primary commodities sector, i.e., downstream to upstream activities. In the modern industries such as electrical and electronics, 
and machinery and transportation, the values of RCA indices recorded for Indonesia are lower than 1.00. In the case of ASEAN, industries that have a competitive advantage in the China market are mainly food, petroleum products, plastics, rubber, and furniture industries (Table 14).

Table 14: Competition in China Markets: Indonesia and ASEAN (RCA Index)

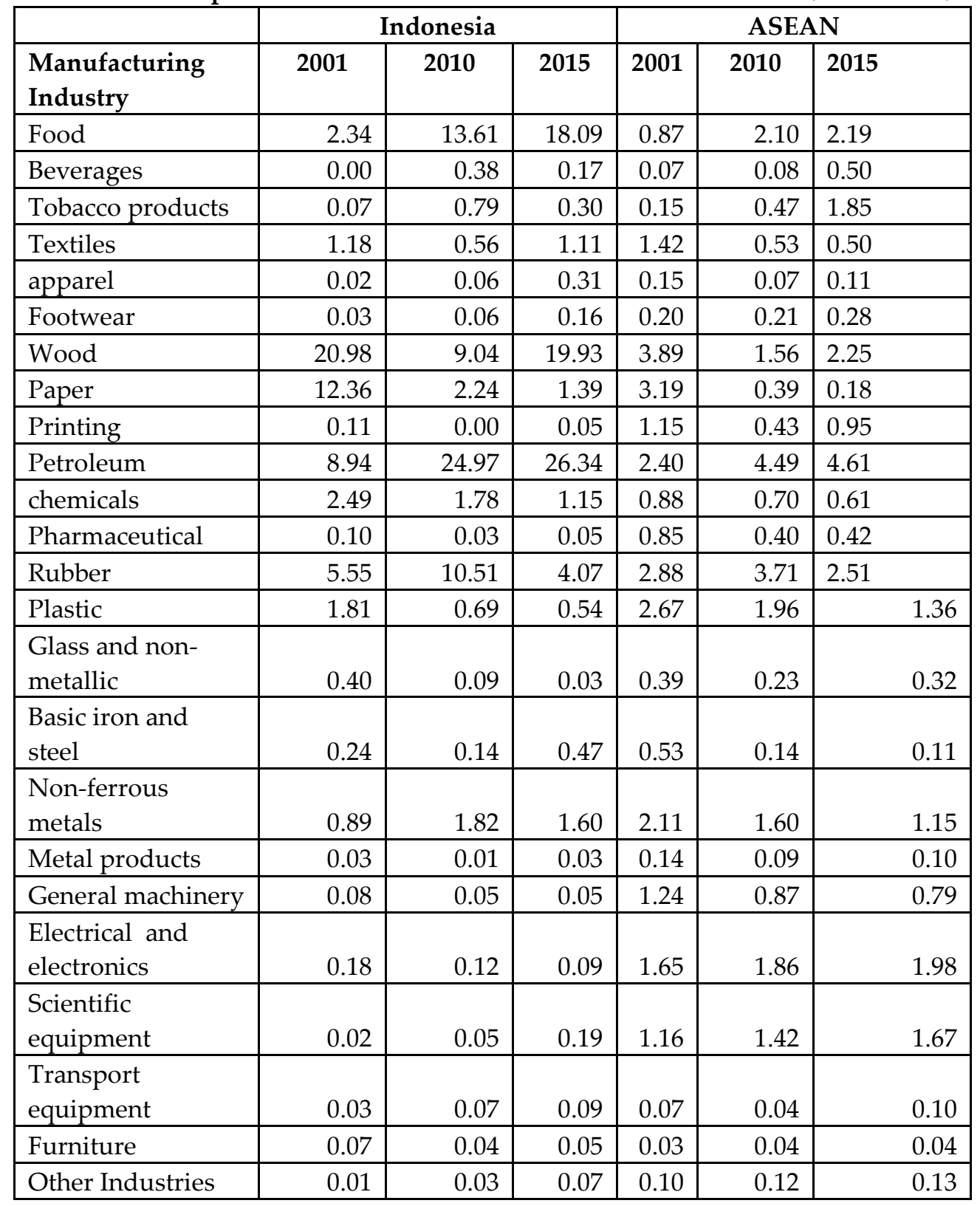


In the case of China's RCA index in the world, China has a competitive advantage in the manufacturing of metal, general machinery and these two industries have a high value of RCA index. The index of these industries show an increasing trend from 2001 to 2015 as depicted in Table 15. China has a competitive advantage in the industries of apparel, footwear, leather, and furniture. However, RCA value trend of those industries are on a decreasing mode. In the ACFTA market, China has a competitive advantage in the textiles, general machinery, E\&E products, and scientific product (Table 15) industries. However, the RCA values calculated for these just mentioned industries had declined but are still higher compared to ASEAN members.

Table 15: China RCA Index: World and Regional

\begin{tabular}{|l|c|c|c|c|c|c|}
\hline & \multicolumn{3}{|c|}{ World } & \multicolumn{3}{c|}{ Regional } \\
\hline Manufacturing Industry & $\mathbf{2 0 0 1}$ & $\mathbf{2 0 1 0}$ & $\mathbf{2 0 1 5}$ & $\mathbf{2 0 0 1}$ & $\mathbf{2 0 1 0}$ & $\mathbf{2 0 1 5}$ \\
\hline Food & 0.78 & 0.34 & 0.30 & 0.67 & 0.33 & 0.41 \\
\hline Beverages & 0.34 & 0.10 & 0.13 & 3.11 & 1.11 & 1.11 \\
\hline Tobacco products & 0.40 & 0.27 & 0.23 & 1.10 & 0.99 & 0.79 \\
\hline Textiles & 1.91 & 2.04 & 2.01 & 2.03 & 1.53 & 1.44 \\
\hline apparel & 3.98 & 3.28 & 2.62 & 1.04 & 0.60 & 0.61 \\
\hline Footwear & 3.53 & 2.32 & 2.04 & 1.11 & 0.64 & 0.74 \\
\hline Wood & 0.74 & 0.66 & 0.62 & 0.30 & 0.31 & 0.32 \\
\hline Paper & 0.33 & 0.51 & 0.82 & 1.04 & 0.87 & 0.97 \\
\hline Printing & 0.42 & 0.53 & 0.61 & 1.28 & 0.72 & 0.93 \\
\hline Petroleum & 0.31 & 0.10 & 0.10 & 0.70 & 0.61 & 0.61 \\
\hline chemicals & 0.75 & 0.70 & 0.71 & 0.92 & 0.68 & 0.65 \\
\hline Pharmaceutical & 0.14 & 0.09 & 0.09 & 0.78 & 0.26 & 0.37 \\
\hline Rubber & 0.65 & 0.80 & 0.83 & 0.41 & 0.22 & 0.25 \\
\hline Plastic & 0.78 & 0.65 & 0.81 & 0.80 & 0.66 & 0.72 \\
\hline Glass and non-metallic & 0.80 & 0.62 & 0.73 & 1.28 & 0.92 & 1.10 \\
\hline Basic iron and steel & 0.90 & 0.97 & 1.23 & 1.29 & 0.96 & 1.16 \\
\hline Non-ferrous metals & 0.62 & 0.53 & 0.61 & 1.88 & 0.90 & 1.12 \\
\hline Metal products & 1.81 & 1.64 & 1.73 & 1.08 & 0.70 & 0.85 \\
\hline General purpose & & & & & & \\
machinery & 0.83 & 1.56 & 1.28 & 1.01 & 1.10 & 0.96 \\
\hline Electrical and electronics & 1.28 & 1.78 & 1.74 & 0.91 & 1.32 & 1.32 \\
\hline Scientific equipment & 0.86 & 0.98 & 0.92 & 0.84 & 1.62 & 1.37 \\
\hline Transport equipment & 0.28 & 0.53 & 0.39 & 1.59 & 1.28 & 1.03 \\
\hline Furniture & 2.15 & 2.73 & 2.79 & 0.80 & 0.67 & 0.73 \\
\hline Other Industries & 4.14 & 3.08 & 2.78 & 0.95 & 0.61 & 0.72 \\
\hline
\end{tabular}




\section{Hillman Index}

Table 16 shows the Hillman Index for Indonesia and China. In the case of Indonesia, the calculated Hillman index indicates that Indonesia has a high competitive advantage in the industries of food, petroleum, chemical, wood, and rubber. The results trends are consistent with the RCA indices position in the World, regionally, and in the China market. However, the index shows mixed results of certain industries such as electrical and electronics, textiles, and machinery. Based on RCA indices at the World, regional and in China market positions, these industries are non-competitive. The trend of the Hillman index seems to be parallel to the RCA index (value $>1$ ) discussed above. In the case of China, the country has a strong competitive advantage in electrical and electronics, machinery, scientific equipment, and transport equipment industries. For some reason, the results of the Hillman Index in the case of China, is not much different with the RCA indices as reported in Table 16.

Table 16: Indonesia: Hillman Index

\begin{tabular}{|l|r|r|r|r|r|r|r|r|r|}
\hline & \multicolumn{3}{|c|}{ World } & \multicolumn{3}{|c|}{ Regional } & \multicolumn{3}{|c|}{ China Market } \\
\hline $\begin{array}{l}\text { Manufacturing } \\
\text { Industry }\end{array}$ & $\mathbf{2 0 0 1}$ & $\mathbf{2 0 1 0}$ & $\mathbf{2 0 1 5}$ & $\mathbf{2 0 0 1}$ & $\mathbf{2 0 1 0}$ & $\mathbf{2 0 1 5}$ & $\mathbf{2 0 0 1}$ & $\mathbf{2 0 1 0}$ & $\mathbf{2 0 1 5}$ \\
\hline Food & 0.2 & 0.1 & 0.1 & 0.2 & 0.1 & 0.1 & 0.2 & 0.0 & 0.0 \\
\hline Beverages & 21.0 & 19.9 & 10.1 & 10.2 & 14.1 & 6.7 & .0 & 41.0 & 64.2 \\
\hline Tobacco products & 1.9 & 2.1 & 1.4 & 0.7 & 1.5 & 0.9 & 97.2 & 19.1 & 55.2 \\
\hline Textiles & 0.2 & 0.3 & 0.3 & 0.2 & 0.6 & 0.4 & 0.2 & 0.5 & 0.3 \\
\hline apparel & 0.1 & 0.1 & 0.1 & 0.5 & 1.1 & 0.4 & 2.2 & 1.4 & 0.3 \\
\hline Footwear & 1.3 & 3.9 & 3.2 & 3.0 & 4.2 & 3.7 & 9.6 & 10.6 & 4.0 \\
\hline Wood & 0.1 & 0.3 & 0.2 & 0.1 & 0.4 & 0.2 & 0.0 & 0.1 & 0.1 \\
\hline Paper & 0.3 & 0.3 & 0.4 & 0.2 & 0.4 & 0.4 & 0.1 & 0.7 & 0.9 \\
\hline Printing & 21.3 & 27.3 & 35.5 & 41.1 & 57.9 & 25.4 & 46.8 & 2034.9 & 124.8 \\
\hline Petroleum & 0.0 & 0.0 & 0.0 & 0.1 & 0.0 & 0.0 & 0.0 & 0.0 & 0.0 \\
\hline chemicals & 0.3 & 0.3 & 0.3 & 0.1 & 0.2 & 0.2 & 0.1 & 0.1 & 0.2 \\
\hline Pharmaceutical & 6.9 & 4.7 & 2.4 & 4.7 & 6.1 & 1.9 & 33.6 & 106.7 & 61.0 \\
\hline Rubber & 0.4 & 0.1 & 0.2 & 0.6 & 0.2 & 0.5 & 0.3 & 0.1 & 0.3 \\
\hline Plastic & 0.5 & 0.7 & 0.6 & 0.3 & 0.5 & 0.5 & 0.2 & 0.6 & 0.6 \\
\hline $\begin{array}{l}\text { Glass and non- } \\
\text { metallic }\end{array}$ & 0.4 & 0.6 & 0.2 & 0.2 & 0.4 & 0.2 & 1.0 & 4.2 & 9.6 \\
\hline Basic iron and steel & 0.7 & 0.6 & 0.4 & 0.4 & 0.5 & 0.5 & 1.3 & 1.6 & 0.4 \\
\hline Non-ferrous metals & 0.4 & 0.2 & 0.3 & 0.2 & 0.1 & 0.2 & 0.9 & 0.4 & 0.4 \\
\hline Metal products & 4.6 & 4.8 & 5.8 & 4.5 & 2.7 & 5.5 & 18.4 & 52.6 & 22.4 \\
\hline General machinery & 0.2 & 0.3 & 0.3 & 0.1 & 0.2 & 0.2 & 0.9 & 1.0 & 1.2 \\
\hline $\begin{array}{l}\text { Electrical and } \\
\text { electronics }\end{array}$ & 0.1 & 0.1 & 0.2 & 0.1 & 0.1 & 0.1 & 0.3 & 0.3 & 0.4 \\
\hline Scientific equipment & 1.0 & 1.4 & 1.2 & 0.9 & 1.2 & 1.4 & 14.0 & 5.7 & 1.5 \\
\hline
\end{tabular}




\begin{tabular}{|l|r|r|r|r|r|r|r|r|r|}
\hline Transport equipment & 0.9 & 0.3 & 0.2 & 0.5 & 0.2 & 0.2 & 8.5 & 2.5 & 2.2 \\
\hline Furniture & 0.4 & 0.7 & 0.8 & 1.5 & 4.3 & 3.2 & 5.1 & 7.3 & 4.3 \\
\hline Other Industries & 1.7 & 2.4 & 1.7 & 3.9 & 6.0 & 2.4 & 19.7 & 13.4 & 5.4 \\
\hline
\end{tabular}

Based on Hillman and RCA indices, Indonesia and ASEAN are incapable of competing with China in textiles and clothing, and in particular the electrical and electronics industry.

\section{Conclusion}

An FTA is a trade bloc that allows members of the pact or bloc to trade goods and services across borders freely with each other. The free mobility of goods in the bloc will build specialisation in production and trade. Some members may receive a trade gain in the form of comparative advantage and some members may receive a trade diversion due to the non-competitiveness of a particular good or industry.

In the case of ACFTA, we expect that there would not be a total gain to members of ASEAN. Certain members may receive gains in the form of trade creation and other members may receive trade diversion. There will be some industries that ASEAN may face losses. One of those industries is textiles and clothing. Producers and enterprises in ASEAN were worried that imports of goods from China that are duty-free will threaten local business survival with the flooding of China's cheaper products in the domestic market. The exports of textiles and clothing, toys, processed foodstuffs, and even machinery and equipment have dropped in response to economic integration with China. ASEAN countries that heavily depend on labour intensive industries feel the pain and SMEs are the most affected in the short to medium run. For example, on the one hand there are reports that many textile and clothing firms in Malaysia, Indonesia, Malaysia, the Philippines, Singapore, and Thailand have closed, requiring further investigation. On the other hand, China seems to have substantially gained in terms of trade creation.

Indonesia was selected to look at the impacts of ACFTA on a country's manufacturing sector. Based on analysis, this paper shows that trade between Indonesia and China is a primary commodities-finished products relationship, i.e., Indonesia produces and exports primary commodities to China and imports manufactured goods from China. Indonesia has strong competitiveness in industries belonging to the primary sector while China has a strong competitiveness in manufacturing finished products. The performance of manufacturing industries in the form of exporting and 
dominating regional commodities market Indonesia vis-à-vis China looks rather bleak. From what has been reported in newspapers and in other form of media regarding the negative impacts of the ACFTA on Indonesian market goods, it seems that some of the reports are true as discussed earlier in this paper. Complaints made by KADIN, textile and clothing associations and other business chambers mentioned above in section 2 actually have a basis. The ACFTA had actually produced a negative impact to Indonesian manufacturing sector performance and manufacturing firms. Therefore, this paper supports the argument that the ACFTA to a certain extent has reduced the competitiveness of Indonesian goods in the regional market as well as in the domestic market.

\section{References}

Ando, M., \& Kimura, F. (2013). Production linkage of Asia and Europe via Central and Eastern Europe. Journal of Economic Integration, 28(2), 20440.

AntaraNews. (2009, 3 December). ASEAN-China FTA to threaten RI steel, textile industries. $\quad$ Retrieved from http://www.antara.co.id/en/news/1259790131/asean-china-fta-tothreaten-ri-steel-textile-industries

Ardian Wibisino. (2010, 13 January). Textile companies to find banks stingy, Bank Indonesia says. The Jakarta Globe.

Buszynski, L. (2001). ASEAN and the future of Southeast Asian regionalism. The Indonesian Quarterly, XXIX(3), 277-285.

Chandra, A. C. (2005). Indonesia and bilateral trade agreements. The Pacific Review, 18(4), 541-565.

Ferto, I., \& Hubbard, L. J. (2003). Revealed comparative advantage and competitiveness in Hungarian agri-food sectors. The World Economy, 26, 247-259.

Greenaway, Mahabir, A., \& Milner, C. (2008). Has China displaced other Asian countries' exports? China Economic Review, 19(2), 152-169.

Grubel, H. G., \& Lloyd, P. P. J. (1975). Intra-industry trade: The theory and measurement of international trade in differentiated products. New York: Wiley.

Hariharan, M. (2010, 12 January). Asean-China FTA: Indonesian drama unfolds. Retrieved from http://www.icis.com/blogs/asian-chemicalconnections/2010/01/asean-china-fta-indonesian-dra/ 
Hassen Saheed. (2006). Prospects for the textile and clothing industry in Indonesia. Retrieved from http://www.textilesintelligence.com/

Hillman, A. L. (1980). Observations on the relation between 'Revealed Comparative Advantage' and Comparative Advantage as indicated by pre-trade relative prices'. Weltwirtschaftliches Archiv, 116(3), 315-321.

Hinloopen, J., \& Marrewijk, C. V. (2001). On the empirical distribution of the Balassa index. Weltwirtschaftliches Archiv, 137(1), 1-35.

Hinloopen, J., \& Marrewijk, C. V. (2008). Empirical relevance of the Hillman condition for revealed comparative advantage: 10 stylized facts. Applied Economics, 40(18), 2313-2328.

Kompas. (2010, 6 January). FTA tetap dilaksanakan, pemerintah janji cari solusi. Retrieved from http://bisniskeuangan.kompas.com/read/2010/01/06/08185354/FTA.Tet ap.Dilaksanakan..Pemerintah.Janji.Cari.Solusi

Kompas. (2011, 10 October). Kentang pun korban ACFTA. Retrieved from https://nasional.kompas.com/read/2011/10/10/20260499/kentang.pun.k orban.acfta

Lardy, N. R. (2002). Integrating China into the global economy. Washington DC: Brookings Institution.

Lim, I., \& Kauppert, P. (2010). Facing a political lock-in situation with the ACFTA: Which options for Indonesia? FES Jakarta. Retrieved from http://library.fes.de/pdf-files/bueros/indonesien/07101-20100325.pdf

Linda Yulisman. (2015, 9 May). Textile sector to get Rp 3 trillion investment this year. The Jakarta Post. Retrieved from http://www.thejakartapost.com/news/2015/05/09/textile-sector-get-rp3-trillion-investment-year.html\#sthash.3O4WKbRT.dpuf

Lo, C. (2003). When Asia meets China in the new millennium. Singapore: PearsonPrentice Hall.

Marchese, S., \& Simone, F. N. D. (1989). Monotonicity of indices of "revealed" comparative advantage: Empirical evidence on Hillman's condition. Weltwirtschaftliches Archiv, 125(1), 158-167.

Mohamed Aslam. (2004). Kawasan Perdagangan Bebas (FTA) ASEAN-CHINA: Impak ke atas ekonomi ASEAN dan Malaysia. JATI, 9, 75-88.

Mohamed Aslam. (2012). ASEAN-China Free Trade Area: The impact on ASEAN Trade and export industries in Malaysia. Saarbrucken: Lambert Academic Publishing.

Mustaqim Adamrah. (2010, 19 February). Employers, unions unite in fear of imports. The Jakarta Post. 
Nasrudin, Bonar M. Sinaga, Muhammad Firdaus, \& Dedi Walujadi. (2015). Dampak ASEAN Free Trade Agreement (ACFTA) terhadap kinerja perekonomian dan sektor pertanian Indonesia (The impact of ASEANChina Free Trade Agreement (ACFTA) on Indonesia's economic performance and agriculture sector). Buletin Ilmiah Litbang Perdagangan, 9(1), 1-23.

Ocean. (2010). Strategy to face ACFTA. Retrieved from http://anoceanofnoise.com/2010/12/

Pangestu, M., Rahardja, S., \& Ing, L. Y. (2015). Fifty years of trade policy in Indonesia: New world trade, old treatments. Bulletin of Indonesia Economic Studies, 51(2), 239-61.

Panitchpakdi, S., \& Clifford, M. L. (2002). China and the WTO: Changing China, changing world trade. Singapore: John Wiley and Sons (Asia).

Setyari, N. P. W., Widodo, T., \& Purnawan, M. (2015). Industrial capital intensity and comparative advantages dynamism of Indonesia export products. Jurnal Ekonomi Pembangunan, 16(2), 107-120.

Tei, C. Y., \& Mohamed Aslam. (2013). The ASEAN-China FTA: Manufacturer associations' views on impacts to the ASEAN textile and clothing sector. JATI, 18, 89-110.

The global competitiveness report 2014-2015. (2014). Retrieved from http://www3.weforum.org/docs/WEF_GlobalCompetitivenessReport_ 2014-15.pdf

The Jakarta Post. (2010, 9 February). RI sends letter to China to renegotiate ACFTA. Retrieved from http://www.thejakartapost.com/news/2010/02/09/ri-sends-letter-chinarenegotiate-acfta.html\#sthash.QPINq1Cq.dpuf

Trade Map. (n.d.). Retrieved from https://www.trademap.org

Vanzetti, D., Setyoko, N. R., Nguyen, N. Q., \& Trewin, R. (2011). A comparison of Indonesian and Vietnamese approaches to agriculture in the ASEAN-China FTA. Paper presented at the 55th AARES Annual Conference, Melbourne, Australia, 8-11 February.

World Trade Organisation. (n.d.). Retrieved from https:/www.wto.org/

Yao, S. (2008). Chinese foreign trade performance and the China-US trade: 19952004 --- A graphical analysis based on China customs statistics. Washington, DC: International Trade Commission.

Zain, W. (2011, 26 April). The pain, gain from ACFTA. The Jakarta Post. Retrieved from http://www.thejakartapost.com/news/2011/04/25/thepain-gain-acfta.html 
Zhao, C., \& Jiang, D. (2009). FDI, capital formation, and economic growth of Western China: A comparison across three regions. In Saw S.-H. \& J. Wong (Eds.), Regional economic development in China (pp. 260-276). Singapore: ISEAS Publishing.

Date Received: 15 November 2017 Date of acceptance: 15 April 2018 